\title{
CEO overconfidence and dividend policy: evidence from Tiger Cub Economies
}

\begin{abstract}
This study aimed to investigate the effect of CEO overconfidence and dividend policy in Tiger Cub Economies which are Indonesia, Malaysia, Philippines, Thailand, and Vietnam. This research also examined the determinants of dividend policy that includes lagged dividend payment, firm size, growth, profitability, free cash flow, leverage, and liquidity. A sample of 232 public listed firms was selected from Tiger Cub Economies for the data period ranging from 2012 to 2016. Using system generalized method of moment (GMM) estimation, a negative relationship was found between dividend payment and CEO overconfidence, a finding that is consistent with the findings of past research. Moreover, the research finding was robust when a more stringent measure of CEO overconfidence was adopted. Other significant determinants of dividend payment were asset growth, firm leverage, earnings growth, and firm size. The findings indicated reduction in dividends associated with CEO overconfidence in firms with declining asset growth, lower firm leverage, higher earnings growth, and larger firm size.
\end{abstract}

Keyword: CEO overconfidence; Managerial overconfidence; Dividend policy; Behavioral corporate finance 